\title{
Hoplolaimus puertoricensis n.sp. (Nematoda: Hoplolaimidae)
}

\author{
Carmen T. Ramirez ${ }^{1}$
}

\section{INTRODUCTION}

Large numbers of parasitic nematodes are frequently found associated with our sugarcane soils. Among them, lance nematodes of the genus Hoplolaimus are sometimes encountered. On a recent collection of soil samples made in the Luce \& Co. sugarcane fields at Santa Isabel, P.R., some specimens of Hoplolaimus were found, showing characters which make them different from all other described species.

The specimens were killed by gentle heat, fixed in FAA, and passed through Thorne's method of desiccating and mounting in glycerin. Permanent mounts were made and added to the Nematode Collection of the Agricultural Experiment Station of the University of Puerto Rico. The description of the new species is as follows:

HOPLOLAIMUS PUERTORICENSIS N.SP.

\section{MIeasurements}

Females: $1.3-1.7 \mathrm{~mm}$; $a-28-35 ; b-7.2-10.8 ; c-32-63 ; V-17-32 / 46-56 /$ $18-31$

Holotype: $1.4 \mathrm{~mm} . ; a-32 ; b-7.2 ; c-53 ; V-32 / 53 / 30$

Males: Not observed.

\section{Description}

Female: Body cylindroid, slightly arcuate when relaxed by gentle heat. Lip region distinctly offset, with 3 annules marked by 6-9 longitudinal striae. In face view 6 lips are seen with 1 papilla on each submedian lip. Amphids slitlike. Cephalic framework prominent with 6 segments, the ventral and dorsal ones bifurcated. Spear, massive, 41-45 $\mu$ long with tulip-shaped knobs. Cuticle annules, about $1 \mu$ apart, continous around body except on tail (fig. 1,K). Hemizonid, 3-9 $\mu$ posterior to excretory pore. Deirids not observed. Scutellum ovate, migratory but always anterior to vulva. Outlet of dorsal esophageal glands 4-6 $\mu$ from spear. Median

1 Former Research Assistant in Nematology, Department of Entomology, Agricultural Experiment Station, University of Puerto Rico, Río Piedras, P.R. The author wishes to express her gratitude to Prof. G. Thorne and Mr. J. Román, Visiting Scientist and Assistant Nematologist, respectively, for their guidance and encouragement during the preparation of this paper. 

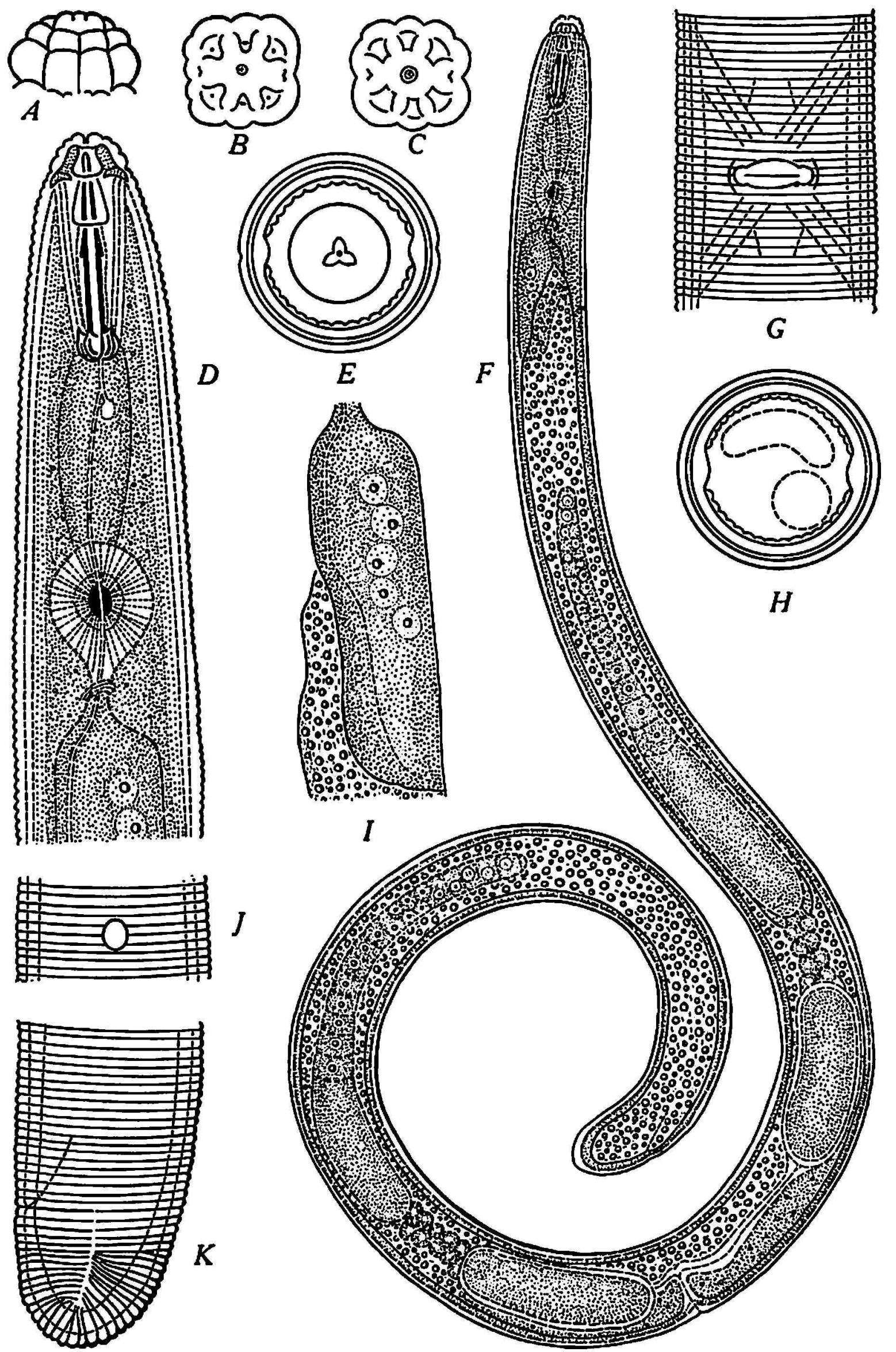

FIG. 1.-Hoplolaimus puertoricensis: A, B, C, $\times 3000 ;$ D, E, G, H, I, J, K, $\times 2000$; F, $\times 600$. A-K, Female: $A$, Lip region; $B$, face view; $C$, basal cephalic framework; $D$, anterior end; $E$, cross-section midway between stylet and middle bulb of esophagus; $F$, entire body; $G$, ventral view of vulva; $H$, cross-section midway between vulva and tail-end; I, esophageal glands showing 5 nuclei; J, scutellum; $K$, tail. 
bulb ovate with prominent valvular apparatus. Isthmus short. Esophageal glands, overlapping intestine dorsolaterally, containing 5 prominent nuclei. Intestine granulated, extending into tail cavity. Terminus broadly rounded, annulated. Vulva, transverse, slitlike, equatorial. Ovaries paired, outstretched. Oöcytes in single file except for a short region of multiplication close to distal end. Spermathecae not present. Some specimens were observed attacked by Duborcquia, a sporozoan parasite.

Male: Not observed.

Holotype: Female from soil collected by G. Thorne and J. Román on October 31, 1962. Slide Hoplolaimus 1,b, Nematology Permanent Collection, Entomology Department, Agricultural Experiment Station, Río Piedras, P.R.

Paratypes: Same data as for holotype. Slides Hoplolaimus 1 through $1 \mathrm{~h}$. Type locality: Luce \& Co. sugarcane field, Santa Isabel, P.R.

Type host: Sugarcane, Saccharum officinarum L.

\section{Diagnosis}

Hoplolaimus puertoricensis is distinguished from all other members of the genus by the presence of only three cephalic annules and five esophageal glands nuclei.

\section{SUMMARY}

Among the parasitic nematodes found on sugarcane soils in Puerto Rico, a new species of the genus Hoplolaimus was found on soil samples from the Luce \& Co. sugarcane fields, in Santa Isabel. A description of the nematode Hoplolaimus puertoricensis, as well as figure 1 illustrating it, are given in this article.

\section{RESUMEN}

Entre los nemátodos parasíticos que abundan en los suelos de caña de azúcar de Puerto Rico se encontró una nueva especie perteneciente al género Hoplolaimus, en campos de Luce \& Company, en Santa Isabel. En este artículo se describe y se ilustra esta especie, fig. 1.

\section{BIBLIOGRAPHY}

1. Andrássy, I., Hoplolaimus tylenchiformis Daday, 1905 (Syn. H. coronatus Cobb, 1923) und die Gattungen der Unterfamilie Hoplolaiminae Filipjev, 1936), Nematologica 3 44-56, 1958.

2. Goodey, J. B., Hoplolaimus proporicus, n.sp. (Hoplolaiminae: Tylenchida), Nemalologica 2 108-13, 1957.

3. Loof, P. A. A., and Oostenbrink, M., Die Identitat von Tylenchus robustus de Man., Nematologica 3 34-43, 1958.

4. Perry, V. G., The Subfamily Hoplolaiminae, Nematology, Fundamentals and Recent Advances, with Emphasis on Plant Parasitic and Soil Forms; Univ. N. C. Press, Raleigh, N.C. pp. 185-90, 1960. 
5. Sauer, M. R., Hoplolaimus gracilidens, Radopholus inacqualis and Radopholus neosimilis, three new Tylenchs native to Victoria, Australin, Nematologica 3 97$107,1958$.

6. Steiner; G. and LeHew, R. R., Hoplolainıus bradys, n.sp. (Tylenchidae; Nematodes), the cause of a disease of yam (Dioscorea sp.), Zool. Anz. $101260-4,1933$.

7. Thorne, G., Subfamily Hoplolaiminae Filipjev, 1934, Principles of Nematology, McGraw-Hill Book Co., Inc., New York, N.Y., pp. 182-9, 1961.

8. Whitehead, A. G., Hoplolaimus angustalatus, n.sp. (Hoplolaiminae: Tylenchida), Nematologica 4 99-105, 1959.

9. - Hoplolaimus aberrans, n.sp. (Hoplolaiminae: Tylenchida), Nematologica 4 268-71, 1959. 